\title{
Innovation in the Era of Experience: The Changing Role of Users in Healthcare Innovation
}

\section{Alexandre Trigo ${ }^{1}$}

\begin{abstract}
This article provides an extensive literature review on the changing role of users in innovation, with a particular focus on the healthcare sector. Users have been specifically analyzed by many scholars worldwide due to their significant role as a source of innovation beyond the traditional assumption which considers customers as mere passive adopters of products and services. The increasing, but still scarce, number of studies on this topic has demonstrated the benefits of patient involvement and how a close and continuous relationship between patients and practitioners can lead to permanent cycles of improvements and innovation in healthcare outcomes. In addition to a user-centered approach, innovative patients are actively developing new solutions for their own treatments, likewise for other patients with similar diseases.

Keywords: patient involvement, user innovation, user-centered innovation, interactive innovation, health innovation.
\end{abstract}

\section{INTRODUCTION}

Innovation is an interactive process based on continuous knowledge flows between the innovative actor and its stakeholders (Chesbrough, 2003, 2011; Lundvall, 1988, 1992; Nelson, 1993). Latest studies have attempted to explain how many firms incorporate ideas, insights and knowledge from outside their own boundaries (Christensen \& Lundvall, 2004; Gomes-Casseres, 2003; Gutiérrez-Gracia \& Fernández-de-Lucio, 2009; Powell \& Grodal, 2005; Vega-Jurado). By providing a narrative review of the literature, this paper aims to explore the changing role of users in innovation, with a particular focus on the healthcare sector. Using a snowball sampling technique, special attention is given to the significance of multi-level collaboration among the manifold economic actors that compose the healthcare industry, especially

1 ICEDE Research Group, Facultade de Ciencias Económicas e Empresariais, University of Santiago de Compostela, Av. Burgo das Nacións, s/n, 15782 Santiago de Compostela, Spain, e-mail: alexandretrigo@gmail.com. 
the experiential knowledge and patient involvement along the process of medical research and innovation.

Patients have increasingly played a significant role in healthcare innovation because their experience, practical knowledge and feelings can determine the way healthcare services are provided. Moreover, the new trend of customization of healthcare entails a high level of user involvement and constant information flows between patient and practitioners. The healthcare provision along an integrated patient journey enables practitioners to identify "experience-drivers, value-creating activities and reasons for dissatisfaction and complaints, ideas for service development and innovation" (Echeverri et al., 2013, p. 50).

Despite the steady evolution towards an evidence-based medicine, insufficient attention has been paid in the existing innovation literature to the active performance of users in the public sector and especially in the healthcare industry. This scarcity opposes the statement that the importance of innovation cannot be higher in any other sector than in healthcare since breakthroughs have the potential specific target to improve life quality, cure diseases and save human lives.

In addition to a user-centered approach, innovative patients are actively developing new solutions for their own treatments, likewise for other patients with similar diseases. User innovation also plays a vital role in the healthcare sector as principal source of hope for the treatment of many illnesses, particularly orphan diseases (Habicht, Oliveira \& Shcherbatiuk, 2012; Oliveira, Zejnilovic, Canhão \& von Hippel, 2015). This evidence emphasizes the major value of experience-based learning embodied in the role of patients as innovators.

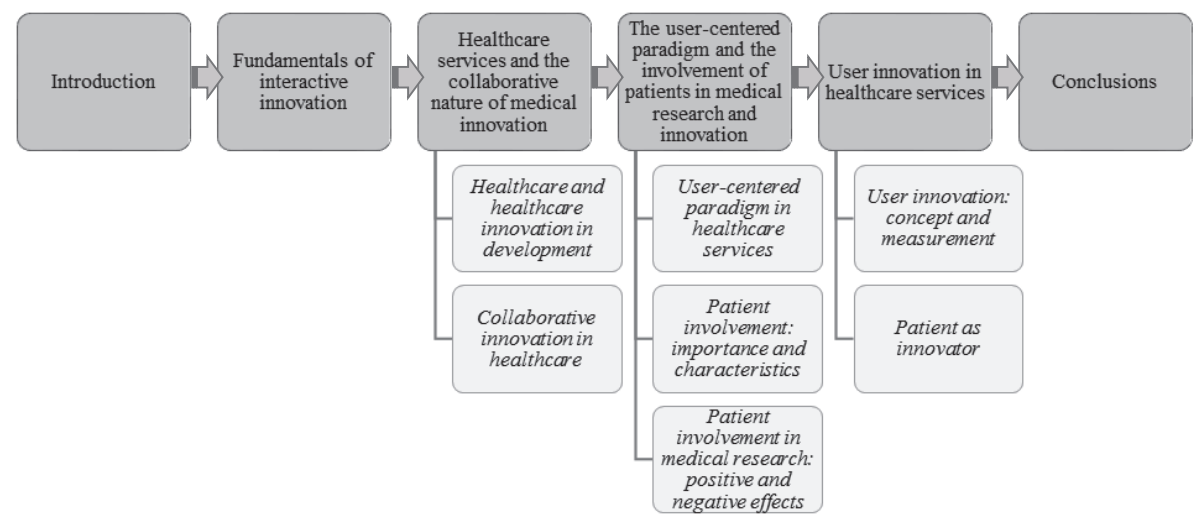

Figure 1. Synthesis of the paper's structure 
As summarized in Figure 1, this paper starts with the fundamentals of interactive innovation and the importance of multi-level collaboration in healthcare services. Among all possible agents implicated in the healthcare delivery system, the subsequent section focuses exclusively on the involvement of patients in medical innovation. In the last section, we discuss the existence of user innovation initiatives, highlighting recent research on patient innovators.

\section{LITERATURE REVIEW}

\section{Fundamentals of interactive innovation}

Generations of innovation models have shown that innovation today emanates from an interactive, multidimensional, integrated, systemic and open process (Chesbrough, 2003; Chesbrough, Vanhaverbeke \& West, 2006; Kline \& Rosenberg, 1986; Lundvall, 1988, 1992; Nelson, 1993; Rothwell, 1992, 1994) in contrast to models where interactions are represented on a linear scale (technology-push and demand-pull). From a systemic perspective, innovation consists of a dynamic and interactive process of creative destruction since the relationship with other economic actors, and the knowledge exchange evoked from this interaction, is the heart of any kind of innovation. Empirical studies have demonstrated that enterprises rarely innovate in isolation of the economic system (Christensen \& Lundvall, 2004). In this regard, cooperation and extramural knowledge exchange have become the basis of the innovation process in many companies. The traditional research and development activity (R\&D) is complementary to many other sources of information such as internal and external partnerships and other types of collaboration which encompass a wide range of actors such as suppliers, customers, universities, technology institutes, government and so forth.

This perspective has caused a significant shift towards a new way of understanding the complex process of innovation. In academia, a new wave of studies has revealed new dimensions including (a) the importance of tacit knowledge (Collins, 1974; Polanyi, 1967), (b) a new generation of dynamic models of innovation (Kline \& Rosenberg, 1986; Rothwell, 1992, 1994), (c) the concept of techno-economics networks (Callon, 1991), (d) the conception of core competence (Leonard-Barton, 1992; Prahalad \& Hamel, 1990), and especially (e) the role of lead users and customer-centered innovation (von Hippel, 1988; von Hippel, 2005; de Jong \& von Hippel, 2009). As a result, new elements have emerged such as (1) the involvement of multiple agents along the innovation process, (2) the access to new knowledge through collaboration, (3) the important role of user experience and (4) the customer as co-creator. 
This new configuration has conditioned the design of new theoretical frameworks for economic and innovation policies such as (a) the evolutionary perspective (Nelson \& Winter, 1982), which describes economic growth as dynamics and evolutionary process of knowledge accumulation and diffusion, (b) system failures (Metcalfe, 1995, 2003), understood as barriers to the innovation, (c) National System of Innovation (Edquist, 1997; Freeman, 1987a, b, 1995; Lundvall, 1992; Nelson, 1993), which applies a holistic approach to the innovation process, laying emphasis on the interaction among different economic actors at the hub of the analysis, (d) the Triple Helix model of knowledgecreation (Etzkowitz \& Leydesdorff, 1997, 2000; Leydesdorff \& Meyer, 2006) which focuses on the importance of interaction and communication among enterprises, universities and governmental institutions, and more recently (e) the Open Innovation Paradigm (Chesbrough, 2003; Chesbrough, Vanhaverbeke \& West, 2006), which accentuates the increasing relevance of external (in addition to the internal) flows of knowledge as enhancement of internal innovation and commercialization of new ideas.

The change from a linear to multi-actor perspective points up the interactive and systemic nature of innovation as well as alternative modes of innovation based on learning by doing, using and interacting (e.g., Jensen, Johnson, Lorenz \& Lundvall, 2007). This mode of innovation differs from the traditional understanding of an innovation process based highly on advancements and improvements derived exclusively from science and technology. While the former mode of innovation lays great emphasis on implicit, tacit knowledge and experience-based learning, the latter one put the accent on explicit, codified knowledge and on formal structures of knowledge transfer. The experiential expertise underlines the value of implicit, tacit knowledge and the process of learning by doing, using and, in the healthcare context, suffering. The user experience plays the role of a third element of a puzzle composed of two more types of knowledge: propositional knowledge ("knowing that") and procedural knowledge ("knowing how") (Caron-Flinterman, Broerse \& Bunders, 2005). The next section goes into some critical factors that have influenced the development of healthcare activities and the way innovation has been conceived in this industry.

\section{Healthcare services and the collaborative nature of medical innovation}

\section{Healthcare and healthcare innovation in development}

Several aspects have been transforming traditional medicine research and healthcare provision over the last few decades. The productivity crisis faced in the healthcare industry is certainly a key factor. Despite the rising share 
of national output (\% of GDP), productivity in the healthcare sector did not grow at the same pace, in part caused by the low level of standardization and the labor-intensive nature of its output (Baumol, 1967; Chesbrough, 2011; Folland, Goodman \& Stano, 2007). In the pharmaceutical industry in particular, the decline in R\&D productivity is mainly a consequence of diminishing returns in the knowledge production function, more challenging therapeutic targets and excessive bureaucracy (LaMattina, 2011; Munos, 2009; Pammolli, Magazzini \& Riccaboni, 2011). The productivity crisis in this sector, and especially in the pharmaceutical realm (Hara, 2003), entailed innovation in multiple facets including incremental changes in internal and external R\&D management, alternative drug development as well as the development of personalized, stratified and regenerative medicine (Mittra, 2016).

Another factor refers to the market access strategies and the patent conflict principally in pharmaceutical industry. As a critical instrument for intellectual property protection in several high tech industries, the patent system has played a pivotal role in healthcare, respectively in pharmaceutical R\&D and innovation (Folland, Goodman \& Stano, 2007; Grabowski \& Vernon, 1990; Grabowski, 2003). In the context of developing countries however, patents had made the prices of new drugs unaffordable. To ensure access to medicines in these countries, differential pricing has been ascribed as a possible approach to attend the needs in both high and low income markets in different countries (Danzon \& Towse, 2003) and within-country via market segmentation (Yadav, 2010).

A third aspect is related to the common practices of mergers and acquisitions (M\&A) over the last decades in the pharmaceutical industry, which have shattered the R\&D activities (LaMattina, 2011; see also Brown, Werling, Walker, Burgdorfer, \& Shields, 2012, for M\&A in the hospital industry). By studying the dynamics of drug innovation since 1950, Munos (2009) demonstrated that the number of new drug approvals is directly correlated to the number of firms involved. His results indicated that "M\&A are not an effective way to promote an innovation culture or remedy a deficit of innovation" (Munos, 2009, p. 961).

Other dominant trends encompass the progress of medical technologies (Spekowius \& Wendler, 2006), the volatility of the healthcare market (Lebrecht, 2015), the patient's perspective of healthcare (World Health Organization, 2007, 2013), the increase in collaborations and partnerships (Consoli \& Ramlogan, 2009; Consoli \& Mina, 2009), among others. In the next subsection we will focus on the collaborative nature of innovation in healthcare. 


\section{Collaborative innovation in healthcare}

The literature on innovation in the healthcare industry has highlighted the increasing importance of external mechanisms of knowledge integration and interfirm R\&D collaboration between pharmaceuticals firms, universities and hospitals (Liebeskind, Oliver, Zucker \& Brewer, 1996; Oliver, 2001; Orsenigo, Pammolli \& Riccaboni, 2001; Quéré, 2004; Powell, 1990; Powell, Koput \& Smith-Doerr, 1996; Powell, White, Koput \& Owen-Smith, 2005; Rai, 2005; Shaw, 1998; Swan et al., 2005; Weigel, 2008) as well as in the context of biotechnology innovation (Broerse \& Bunders, 2000; Roijakkers \& Hagedoorn, 2006; Vence, Sánchez, Rodil, 2013). This evidence endorses the hypothesis that innovation, regardless of industry, relies to a great extent on the continuous and unbounded interaction among an array of actors.

Medical innovation is a valuable example of where interactivity is represented at a multidimensional level in order to discover or improve treatments, therapies and drugs for a wide range of diseases. This collaborative character has increased significantly over the last decade, turning healthcare innovation into an extremely networked system (Consoli \& Ramlogan, 2009). The literature aimed to stress that the role of collaborations and networks in the healthcare industry has become more widespread during the last decades (Cambrosio, Keating, Mercier, Lewison \& Mogoutov, 2006; Consoli \& Mina, 2009; Consoli \& Ramlogan, 2009; Liebeskind et al., 1996; Oliver, 2001; Orsenigo, Pammolli \& Riccaboni, 2001; Powell et al., 2005; Powell, 1990; Powell, Koput \& Smith-Doerr, 1996; Quéré, 2004; Rai, 2005; Ramlogan, Mina, Tampubolon \& Metcalfe, 2007; Shaw, 1998; Swan et al., 2005; Weigel, 2008).

Consoli and Mina (2009) described the health innovation system as a structure composed of the health delivery system and the science and technological system. The constant interaction between both systems and the continuous flow of knowledge represents the basis of the innovation dynamic in this sector. The health delivery system consists of the service provision and the direct relationship between practitioner and patients. The science and technological system, on the other hand, is composed of the technological market, which is responsible for developing new drugs and medical devices, and the scientific community. Among all actors involved in healthcare provision and innovation, the next section considers exclusively the information and knowledge exchange between healthcare providers and patients in medical research and innovation. 
The user-centered paradigm and the involvement of patients in medical research and innovation

\section{User-centered paradigm in healthcare services}

Over the last decades, a new consumer-centric paradigm - where the users play an active and major role as co-developers and co-innovators - has questioned the real scope of the traditional manufacturing-active model (Baldwin \& von Hippel, 2011; von Hippel, 1978a,b, 1986, 1988, 2005; von Hippel \& Katz, 2002; von Hippel \& de Jong, 2010). Among all economic agents involved in the innovation process, users have been specifically analyzed due to their remarkable role as source of innovation contributing with original ideas and experiential wisdom (von Hippel, 1988). Many authors have singled out the major value of experience-based learning and the value of users as an innovation source in several industries (Bower, 2005; Caron-Flinterman et al., 2005; von Hippel, 1988, 2005; Jensen et al., 2007; Lundvall, 1985, 2006, 2007; Rabeharisoa, 2003; Smits \& Boon, 2008). Nevertheless, an overview of these examples leads us to question whether user-centered innovation can also flourish in an industry such as healthcare whose innovation mode is highly based on science and technology. Empirical results show that clinicians can play a major role as lead users via field discovery. Demonaco, Ayfer and von Hippel (2006) have empirically confirmed that a significant number of drug therapy innovations were discovered by clinical practice, bridging practical experience with patients and the Science \& Technology system.

In the patient context, the user-driven innovation paradigm implies that the role of patients has changed from a passive subject of research to an active partner along the innovation process (Mittra, 2016). When the patient is involved, the relevance, the pragmatism as well as the benefits of the research in terms of usefulness, effectiveness and practical efficacy increase. However, evidence reveals that this involvement has mostly been focused on the decisions and the management of chronic illnesses than on research, development and innovation (Echeverri et al., 2013). Additionally, several health professionals are still averse to a closer doctor-patient relationship in certain areas including decision making and choice (Lester, Tait, England \& Tritter, 2006; European Commission, 2012).

The patient involvement in healthcare innovation was proved to be not only a buzzword but a challenging, though profitable, task (Kielstra, 2009; Trivedi \& Wykes, 2002). The expert knowledge required and the patient' low purchasing power have traditionally differentiated patients from consumers in other sectors. However, this panorama is gradually changing and the current evidence demonstrates that they can significantly influence innovation in 
health services. Patients' purchasing power has increased and they have become more concerned and knowledgeable about their own treatment and healing (Røtnes \& Staalesen, 2009).

The conception of patient-centered healthcare systems in collaboration with other economic and societal actors can strengthen the prevention of lifestyle-related illnesses such as cardiovascular disease, cancer or diabetes (Echeverri et al., 2013). Besides, the fruitful implementation of patientfocused care entails cooperation between providers, health plans, and policymakers (Reed, Conrad, Hernandez, Watts \& Marcus-Smith, 2012). The alliance of several societal actors became a key strategy to stimulate and implement ideas and improvements derived from the close patientpractitioner interaction. Indeed, a group of experts, in discussion on the future of healthcare in Sweden, have proposed the creation of a national incubator for patient innovation (Echeverri et al., 2013). Its responsibilities would include the compilation of innovation ideas from different healthcare organizations, assistance during the planning and implementation phase, as well as the link between private entrepreneurs and healthcare organisms. This proposal runs in parallel with the creation of a formal body of governance to operate all kind of initiatives including innovation instruments, knowledge management and dissemination of eHealth as well as social media. The following subsection describes the main attributes of patients that can determine the level of engagement.

\section{Patient involvement: importance and characteristics}

A recent qualitative survey performed across fifteen European Member States underlines that the concept of involvement is not entirely clear for both patients and practitioners, commonly seen as a mere compliance of treatments (European Commission, 2012; see also Sahlsten, Larsson, Sjostrom \& Plos, 2008). User involvement in healthcare comprises different aspects compared to other traditional industries. Thanks to this fact, patientcentered healthcare tends in general to integrate and involve patients instead of letting the patients lead the process (Røtnes \& Staalesen, 2009). For particular disturbances such as stroke, however, lead user methods have been vastly applied to better comprehend how patients experience healthcare (Echeverri et al., 2013).

The engagement and the close cooperation with treatments were demonstrated to be more effective with enlightened and instructed patients. Particularly in hospitals, more than a few patients felt more comfortable to share their experience with nurses, whose relationship "is more likely to be characterized by trust and equality" (European Commission, 2012, p. 37). 
Besides, the involvement is expected to be more intensive with chronically ill patients and those with orphan (rare) diseases (a small and specific market widely neglected by the pharmaceutical industry due to a lack of financial incentives). For these cases, patients are more aware of several aspects of the disease and more experienced in self-monitoring. Additionally, patients with chronic diseases are in general more conscious of alternative treatments (European Commission, 2012), which makes the experiential knowledge a major source of hope for the treatment of many illnesses. The patient' age and likewise the patient' socioeconomic status also contribute to the level of involvement. Empirical results reveal that younger patients with greater income and with greater educational skills are more likely to use touch screen technology, as a way to collect patient feedback data (Zarghom, Fonzo \& Leung, 2013). The positive and negative outcomes from patient involvement in medical research are discussed in the next subsection.

\section{Patient involvement in medical research}

The experiential knowledge has grown to be a key contribution of patients to medical research (Caron-Flinterman et al., 2005), providing expert information based on daily experience of their own diseases. This involvement certainly leads towards significant changes in the focus, in the design and also in the content of the research (Trivedi \& Wykes, 2002). Pioneering initiatives in Nordic countries stress the emergence of new innovation trends toward the adoption of a user-led innovation in the entire public healthcare system, also in hospitals (Røtnes \& Staalesen, 2009; Echeverri et al., 2013). In Sweden, most of the research councils have implemented research and innovation initiatives with a close patient involvement, involving an increase of patient value and costs reduction (Echeverri et al., 2013). Recent health studies and reports put emphasis on the increasing patients' involvement in diagnosis, treatments, therapies and cure of diseases derived from (bio)medical research activities and clinical trials (National Institute for Health Research [NIHR], 2009). Patient-reported outcomes (PROs) is becoming a key element for clinical research, by providing physicians with different types of data and information such as "physical functions, symptoms, global judgments of health, psychological well-being, social well-being, cognitive functioning, role activities, personal constructs, satisfaction with care, health related quality of life [and] adherence to medical regimens" (Deshpande, Rajan, Sudeepthi \& Abdul Nazir, 2011, p. 137).

A significant impact of experiential knowledge of patients was shown in different stages of the medical research, including the development of the grant application, the research design, the data analysis as well as the 
dissemination of research findings (National Institute for Health Research [NIHR], 2010; see also Trivedi \& Wykes, 2002). The following table summarizes the consecutive phases of medical research in which patients could be involved, and their possible contribution.

Table 1. User involvement in medical research The stages of medical The involvement of users can help: research The development of To discuss the research idea and help to focus the question to one the grant application that reflects patients' needs and will benefit patients.

To review the research proposal and offer suggestions from a patient perspective.

To help identify where users could be involved in other areas of the research project.

To be named as a co-applicant for funding and ethics approval.

The research design To identify areas where users could be involved in the research. Inform the design of communication materials to better suit participants, for example:

by helping to make patient information sheets and consent forms more understandable, by reviewing questionnaires and other data collection methods. To identify possible participant recruitment strategies.

To consider the ethical implications of the research and help researchers to understand patient concerns and suggest ways to address these.

To provide an idea of what it is like to take part in research.

The research To identify ways to resolve problems in relation to recruiting or management retaining participants, for example where to advertise and in what format.

The undertaking of To undertake data collection.

the research

The analysis of the To suggest gaps in the data which can help identify further research research data questions.

To provide their interpretation of the data which may be different to that of the research team.

The dissemination of To advise and develop reports on the research findings that are research findings understandable to the public.

To provide suggestions on where to disseminate the findings; who will be interested, how to reach them and in what format. For example, there may be a website forum where you can make your research known, or a patient group you could present to.

To participate in presenting the findings of the research and talk about their experience of being involved in the process.

Source: Own elaboration based on NIHR (2010).

Many authors have underlined numerous benefits from this close partnership among patients, practitioners and researchers. This involvement permits patients to improve their knowledge and research skills (Buckley, Grant, Firkins, Greene, \& Frankau, 2007; Clark, Glasby \& Lester, 2004; Griffiths, Jorm \& Christensen, 2004), converting sick people into proto-professionals 
(Caron-Flinterman et al., 2005), as well as to strengthen patient' esteem and confidence (Clark, Glasby \& Lester, 2004; McCormick, Brody, Brown \& Polk, 2004; Minogue, Boness, Brown \& Girdlestone, 2005). The benefits for patients also include a better understanding of the nature and purpose of the research carried out (Donovan et al., 2002) and the capacity to introduce real needs into the research's objectives (Kent, 2002; Kent \& Oosterwijk, 2007; Wootton, Wood \& Cook, 2008). The advantages also embrace a wider diffusion of findings and, evidently, an increased relevance of the research as well as the results obtained and the methods of analysis (Ali, Roffe \& Crome, 2006; Hanley, Truesdale, King, Elbourne \& Chalmers, 2001; McCormick et al., 2004; Rose, 2003). In addition to the patient-centered care discussed hitherto, the next section examines the user innovation literature in the sphere of healthcare.

\section{User innovation in healthcare services}

\section{User innovation: concept and measurement}

In several industries, best practices in business have increasingly demonstrated that profitable novel or enhanced products, processes and services were originally developed by users, so-called "lead users". This class of users is composed not only of expert, senior professional advisors, but also amateur devotees, passionate insiders, customers and end-users, who are simply aiming to find solutions for their own needs. They are experiencebased experts with strong unsatisfied needs (von Hippel, 1986; Urban \& von Hippel, 1988).

To date, most of the empirical literature on user innovation has been based on in depth and thorough case studies. The list of examples is increasingly extensive and many empirical studies over the last few years have highlighted the existence of user innovation in different contexts such as printed circuit CAD software (Urban and von Hippel, 1988), pipe hanger hardware (Herstatt \& von Hippel, 1992), new medical equipment technology or devices (Biemans, 1991; Lüthje, 2003; Lettl \& Gemünden, 2005), outdoor consumer products (Lüthje, 2004), sport equipment (Franke \& Shah, 2003; Franke, von Hippel \& Schreier, 2006; Lüthje, Herstatt \& von Hippel, 2002), offlabel drug therapies (Demonaco, Ayfer \& von Hippel, 2006), games and toys (Stockstrom, Lüthje \& Antorini, 2010) as well as banking services (Oliveira \& von Hippel, 2011). All these studies have proved that users can modify existing products and services but also create new ones and provide profitable ideas.

The first question that arises from these wide-ranging examples is whether user innovation is a ubiquitous phenomenon. Other cross-industry 
studies observe how user innovation at firm-level varies widely across sector. They also make patent sectoral differences with regard to the levels of user innovation (e.g., Flowers, Sinozic \& Patel, 2009). Hence, although all the aforementioned empirical studies suggest a significant share of user innovation over the total of innovation developed in their respective areas, the presence of innovative users seems to be more predominant in certain sectors than in others like in the healthcare industry. The high level of industrial aggregation in certain studies, and the mere absence of the healthcare sector in others obscure the understanding of the scope of users' integration in healthcare innovation. In the next subsection we provide some examples of patient innovations described in the literature.

\section{Patient as innovator}

Recent case studies have corroborated that even patients can innovate and promote better health practices. An exploratory empirical analysis identified several cases of patient innovation classified into three main categories: rare conditions (including rare or orphan diseases), strong constraint on daily life and dead end situations (Habicht, Oliveira \& Shcherbatiuk, 2012). A chest percussion with electrical percussion, electronic trousers ReWalk and External Aortic Root Support are some examples of innovations developed by patients dealing with adverse health conditions. Indeed, $8 \%$ of patients with orphan (rare) diseases have developed new to the world innovations (Oliveira et al., 2015). Orphan diseases have been widely neglected by the pharmaceutical industry due to a lack of financial incentives to work in this small and specific market. Therefore, patient solutions have not only alleviated and improved the health deficiencies of the self-innovators but also those of other patients with similar diseases. A recent empirical research pointed out that approximately $88 \%$ of those patients who shared their selfdeveloped solutions shared them with other patients, contrasting, however, with only $6 \%$ reported to their doctors and clinicians (Oliveira et al., 2015). In this sense, patient innovation plays a vital role in the healthcare sector being, in certain cases such as orphan diseases, the principal source of hope for the treatment of many illnesses.

The internet and new technologies have become the ideal platforms for patients to share their experience of existing and original treatments. Besides health communities, crowdsourcing sites and smartphone applications (in particular healthcare apps) have all become very popular and available on different platforms. Apart from individual app developers and pharmaceuticals manufacturers, patients have been recognized as important innovators of medical smartphone applications. Heath apps developed by 
patient organizations typically provide emotional support and other patient success stories but present only limited functionality such as information, social media connections and physician recommendations (IMS Institute for Healthcare Informatics, 2013). A recent empirical study based on the top 500 apps in Germany, US and UK demonstrated that patient-developed apps, as well as applications created by healthcare professionals, have been better rated than apps developed by companies or individual developers (Goeldner \& Herstatt, 2016). In most cases, patients had no external support and generated the solutions with their own IT Knowledge. However, most of the identified patient-developed apps did not consider regulations. All health apps aimed at providing information on a disease or other condition are treated as a medical device and subjected to FDA (U.S. Food and Drug Administration) regulations (Food and Drug Administration, 2015).

\section{CONCLUSIONS}

The objective of this paper is to synthesize part of the existing literature on the changing role of users in innovation, with a particular focus on the healthcare sector. The so-called user-centered approach suggests a remarkable revolution in the way innovation has been conceived. User-centered innovation practices have been widely influencing the way new products and services are developed in several industries over the last two decades. However, the traditional mode of innovation performed by the healthcare industry, which is predominantly based on science and technological improvements, casts doubt on whether patient-centered innovation can successfully thrive as it does in other economic activities. The overdue consideration of the value of user involvement - and also of the existence of innovative users - in the referred industry could be ascribed to the research-based model that shaped innovation in life sciences for a long time.

The increasing, but still scarce, number of studies dedicated to this topic coincides with a new trend where patients play a key role in innovation process in both private and public healthcare systems. Experts have demonstrated that the close and continuous relationship between patients and healthcare professionals can lead to permanent cycles of improvements and innovation in healthcare outcomes, including diagnosis, shared decision-making, patientcentered medical care and patient control. In the context of medical research, patients contribute, with their valuable practical experience of dealing daily with the effects of certain diseases, to the research design, the analysis of research data as well as the dissemination of research findings.

In spite of that, the definite benefits from a deeper patient engagement are still unclear to patients and practitioners in several countries, as proved by the Eurobarometer qualitative survey, recently published by the European 
Commission. Also, patient involvement has mostly been confined to the decision making process and the management of chronic diseases, rather than a direct cooperation on R\&D and innovation projects.

Multi-level collaboration between the healthcare system and other economic and societal actors are vital to consolidate a patient-focused care. Instead of singular and punctual programs, a fruitful patient-centered model would benefit from a multi-level body of governance to operate all kind of initiatives including innovation instruments, knowledge management and dissemination of eHealth as well as social media. These mechanisms should also encourage patient innovation in addition to the diffusion of innovative solutions developed by users. The Swedish case cited throughout this article is a successful reference in this field.

This paper also aimed to draw attention to a complementary view, which contemplates the user as innovator. There are already numerous examples of profitable products, processes and even services originally developed by users with different backgrounds and expertise. Although research on lead users has been presented over the last three decades, recent publications on healthcare have revealed pertinent examples of innovative patients. In healthcare, innovative patients are actively developing new solutions for their own treatments, likewise for other sick individuals with similar diseases. We recommend further research on alternative instruments from public and private sectors to stimulate patient innovation mainly in the context of orphan diseases, usually overlooked by the pharmaceutical industry due to a lack of financial incentives. A shift in the producer-centered innovation approach of public policy for healthcare is also needed.

\section{Acknowledgments}

I am grateful to Prof. Dr. Christian Lüthje and his team from the Institute of Innovation Marketing (Hamburg University of Technology, TUHH) for providing guidance, stimulating suggestions and for helpful discussions. I also thank Prof. Xavier Vence and members of the ICEDE (Innovation, Structural Change and Development) Research Group (University of Santiago de Compostela) for their valuable advice. Finally, I would also like to express thanks to the editors and two anonymous referees for their constructive feedback. The usual disclaimer applies.

\section{References}

Ali, K., Roffe, C., \& Crome, P. (2006). What patients want: Consumer involvement in the design of a randomized controlled trial of routine oxygen supplementation after acute stroke. Stroke, 37(3), 865-871. 
Arundel, A., \& Sonntag, V. (1999). Patterns of Advanced Manufacturing Technology (AMT) Use in Canadian Manufacturing: 1998 AMT Survey Results. Science, Innovation and Electronic Information Division Research Paper No. 12. Ottawa: Statistics Canada.

Baldwin, C.Y., \& von Hippel, E. (2011). Modeling a Paradigm Shift: From Producer Innovation to User and Open Collaborative Innovation. Organization Science, 22(6), 1399-1417.

Baumol, W. (1967). Macroeconomics of unbalanced growth: The anatomy of urban crisis. The American Economic Review, 57(3), 416-426.

Biemans, W.G. (1991). User and third-party in developing medical equipment innovations. Technovation, 11(3), 163-182.

Bisgaard, T., \& Høgenhaven, C. (2010). Creating new concepts, products and services with user driven innovation. Oslo, Norway: Nordic Innovation Centre (NICe).

Bower, J. (2005). From the 'Rhetoric of Hope' to the 'Patient-active Paradigm': Strategic Positioning of Pharmaceutical and Biotechnology Companies. Technology Analysis \& Strategic Management, 17(2), 183-204.

Broerse, J., \& Bunders, J. (2000). Requirements for biotechnology development: The necessity of an interactive and participatory innovation process. International journal of biotechnology, 2(4), 275-296

Brown, T.C.Jr., Werling, K.A., Walker, B.C., Burgdorfer, R.J., \& Shields, J.J. (2012). Current trends in hospital mergers and acquisitions. Healthcare Financial Management, 66(3), 114-118, 120.

Buckley, B., Grant, A., Firkins, L., Greene, A., \& Frankau, J. (2007). Working together to identify research questions. Continence, 1(1), 76-81.

Callon, M. (1991). Techno-economic networks and irreversibility. In Law, J. (Ed.), A sociology of monsters: essays on power, technology and domination. London, England: Routledge, 132-161.

Callon, M. (1994). Is Science a Public Good?. Science, Technology and Human Values, 19(4), 395-424.

Cambrosio, A., Keating, P., Mercier, S., Lewison, G., \& Mogoutov, A. (2006). Mapping the emergence and development of translational cancer research. European Journal of Cancer, 42(18), 3140-3148.

Caron-Flinterman, J.F., Broerse, J.E., \& Bunders, J.F. (2005). The experiential knowledge of patients: a new resource for biomedical research?. Social Science \& Medicine, 60(11), 2575-2584.

Chesbrough, H. (2003). Open Innovation: The New Imperative for Creating and Profiting from Technology. Boston, Mass.: Harvard Business School Press.

Chesbrough, H. (2011). Open Services Innovation: Rethinking Your Business to Grow and Compete in a New Era. San Francisco, CA: Jossey-Bass.

Chesbrough, H., Vanhaverbeke, W., \& West, J. (Eds.). (2006). Open Innovation: Researching a New Paradigm. Oxford, United Kingdom: Oxford University Press. 
Christensen, J. L., \& Lundvall, B.-Å. (Eds.). (2004). Product Innovation, Interactive Learning and Economic Performance. Amsterdam, Netherlands: Elsevier.

Clark M., Glasby J., \& Lester H. (2004). Cases for change: User involvement in mental health services and research. Research Policy and Planning, 22(2), 31-38.

Collins, H. (1974). The TEA set: Tacit knowledge and scientific networks. Science Studies, 4, 165-186.

Consoli, D., \& Mina A. (2009) An evolutionary perspective on the dynamics of Health Innovation Systems. Journal of Evolutionary Economics, 19(2), 297-319.

Consoli, D., \& Ramlogan, R. (2009). Scope, Strategy and Structure: The Dynamics of Knowledge Networks in Medicine. Manchester Business School Working Paper Number 569, University of Manchester.

Danzon, P. M., \& Towse, A. (2003). Differential Pricing for Pharmaceuticals: Reconciling Access, R\&D and Patents. International Journal of Health Care Finance and Economics, 3(3), 183-205.

de jong, J.P.J., \& von Hippel, E. (2009). Transfers of user process innovations to process equipment producers: A study of Dutch high-tech firms. Research Policy, 38(7), 1181-1191.

Demonaco, H.J., Ayfer, A., \& von Hippel, E. (2006). The Major Role of Clinicians in the Discovery of Off-Label Drug Therapies, Pharmacotherapy, 26(3), 323-332.

Deshpande, P.R., Rajan, S., Sudeepthi, B.L., \& Abdul Nazir, C.P. (2011). Patientreported outcomes: a new era in clinical research. Perspectives in clinical research, 2(4), 137-144.

Donovan, J., Mills, N., Smith, M., Brindle, L., Jacoby, A., Peters, T., Frankel, S., Neal, D., \& Hamdy, F. (2002). Quality improvement report: Improving design and conduct of randomised trials by embedding them in qualitative research: ProtecT (prostate testing for cancer and treatment) study. British Medical Journal, 325(7367), 766-770. doi: http://dx.doi. org/10.1136/bmj.325.7367.766.

Echeverri, P., Skålén, P., Hjalmarson, H., Gäre, B.A., Svensson, H., Henriks, G., Hellström, A., \& Elg, M. (2013). Patient involvement for service innovation - An agenda for research and innovation in healthcare and social service. Service Research Center, Karlstad University. Retrieved from https://www.kau.se/ctf/involve

Edquist, C. (Ed.). (1997). Systems of Innovations. London, United Kingdom: Pinter Publishers.

Etzkowitz, H. and Leydesdorff, L. (Eds.) (1997). Universities in the Global Economy: A Triple Helix of University-Industry-Government Relations. London, United Kingdom: Cassell Academic.

European Commission (2007). Innobarometer 2007. Brussels, Belgium: DG Enterprise and Industry. 
European Commission (2009). Innobarometer 2009. Brussels, Belgium: DG Enterprise and Industry.

European Commission (2012). Eurobarometer Qualitative Study, Patient Involvement: Aggregate Report, Brussels, Belgium: DG COMM R\&S Unit.

Flowers, S., Sinozic, T., \& Patel, P. (2009). Prevalence of User Innovation in the EU: Analysis based on the Innobarometer Surveys of 2007 and 2009. INNO-Metrics Thematic Paper.

Folland, S., Goodman, A.C., \& Stano, M. (2007). The Economics of Health and Health Care ( $5^{\text {th }}$ ed.). Upper Saddle River, NJ: Pearson Prentice Hall.

Food and Drug Administration (2015). Mobile Medical Applications: Guidance for Industry and Food and Drug Administration Staff. Retrieved from http://www.fda.gov/downloads/MedicalDevices/.../UCM263366.pdf

Franke, N., \& Shah, S. (2003). How Communities Support Innovative Activities: An Exploration of Assistance and Sharing among End-Users. Research Policy, 32(1), 157-178.

Franke, N., von Hippel, E., \& Schreier, M. (2006). Finding Commercially Attractive User Innovations: A Test of Lead User Theory. Journal of Product Innovation Management, 23(4), 301-315.

Freeman, C. (1987a). Factor Substitution and the Instability of Growth. Paper prepared for a Symposium at the Institute of Statistical Research, Tokyo, Japan on $23^{\text {rd }}$ and $24^{\text {th }}$ September 1987.

Freeman, C. (1987b). Technology and Economic Performance: Lessons from Japan. London, United Kingdom: Pinter Publishers.

Freeman, C. (1995). The National System of Innovation in Historical Perspective. Cambridge Journal of Economics, 19(1), 5-24.

Goeldner, M., \& Herstatt, C. (2016). Are Patients and Relatives the Better Innovators? The case of medical smartphone applications. Institute for Technology and Innovation Management Working Paper Number 91, Hamburg University of Technology (TUHH).

Gomes-Casseres, B. (2003). Competitive advantage in alliance constellations. Strategic Organization, 1(3), 327-335.

Grabowski, H. (2003). Patents and new product development in the pharmaceutical and biotechnology industries. The Georgetown Public Policy Review, 8(2), 7-23.

Grabowski, H. G., \& Vernon, J.M. (1990). A new look at the returns and risks to pharmaceutical R\&D. Management Science, 36(7), 804-821.

Griffiths K.M., Jorm A.F., \& Christensen H. (2004). Academic consumer researchers: A bridge between consumers and researchers. Australian and New Zealand Journal of Psychiatry, 38(4), 191-196.

Habicht, H., Oliveira, P., \& Shcherbatiuk, V. (2012). User Innovators: When Patients Set Out to Help Themselves and End Up Helping Many. Die Unternehmung, 66(3), 277-294.

Hanley B., Truesdale A., King A., Elbourne D., \& Chalmers I. (2001). Involving consumers in designing, conducting, and interpreting randomised 
controlled trials: Questionnaire survey. British Medical Journal, 322(7285), 519-523. doi: http://dx.doi.org/10.1136/bmj.322.7285.519.

Hara, T. (2003). Innovation in the Pharmaceutical Industry: the process of drug discovery and development. Northampton, MA: Edward Elgar Publications.

Herstatt, C., \& von Hippel, E. (1992). From Experience: Developing New Product Concepts via the Lead User Method. Journal of Product Innovation Management, 9(3), 213-222.

IMS Institute for Healthcare Informatics (2013). Patient apps for improved healthcare: From novelty to mainstream. Parsippany, NJ, IMS Institute.

Jensen, M. B., Johnson, B., Lorenz, E., \& Lundvall, B.-Å. (2007). Forms of Knowledge and modes of innovation. Research Policy, 36(5), 680-693.

Kent A. (2002). Patients + research = result! the role of patients and their interest groups in biomedical research. EMBO Reports, 3(8), 707-708. doi: 10.1093/embo-reports/kvf166.

Kent A., \& Oosterwijk C. (2007). A patient and family perspective on gene therapy for rare diseases. Journal of Gene Medicine, 9(10), 922-923. doi: 10.1002/jgm.1097.

Kielstra, P. (2009). Doctor Innovation: Shaking Up the Health System. Economist Intelligence Unit. Retrieved from http://graphics.eiu.com/ marketing/pdf/Philips_Shaking_up.pdf

Kline, S. J., \& Rosenberg, N. (1986). An overview of innovation. In Landau, R., \& Rosenberg, N. (Eds.), The Positive sum strategy: harnessing technology for economic growth (pp. 275-305). Washington D.C.: National Academy Press.

Lamattina, J. L. (2011). The impact of mergers on pharmaceutical R\&D. Nature Reviews Drug Discovery, 10, 559-560. doi:10.1038/nrd3514

Lebrecht, A. (2015). Past Trends and Future Forecasts in a Volatile Healthcare Market. Poster presented at LVHN Research Scholar Program Poster Session, Lehigh Valley Health Network, Allentown, PA. Retrieved from http://scholarlyworks.Ivhn.org/cgi/viewcontent.cgi?article=1417\&conte $\mathrm{xt}=$ research-scholars-posters

Leonard-Barton, D. (1992). Core capabilities and core rigidities: a paradox in managing new product development. Strategic Management Journal, 13(S1), 111-125. doi: 10.1002/smj.4250131009

Lester, H., Tait, L., England, E., \& Tritter, J. (2006). Patient involvement in primary care mental health: a focus group study. British Journal of General Practice, 56(527), 415-422.

Lettl, C., \& Gemünden, H. G. (2005). The entrepreneurial role of innovative users. Journal of Business \& Industrial Marketing, 20(7), 339-346. doi: $10.1108 / 08858620510628579$

Leydesdorff, L., \& Meyer, M. (2006). Triple Helix indicators of knowledgebased innovation systems: introduction to the special issue. Research Policy, 35(10), 1441-1449. 
Liebeskind, J. P., Oliver, A. L., Zucker, L., \& Brewer, M. (1996). Social networks, learning, and flexibility: Sourcing scientific knowledge in new biotechnology firms. Organization Science, 7(4), 428-443.

Lundvall, B.-Å. (1985). Product Innovation and User-Producer Interaction. Aalborg, Denmark: Aalborg University Press.

Lundvall, B.-Å. (1988). Innovation as an interactive process: from userproducer interaction to the national system of innovation. In Dosi, G. Freeman, C., Nelson, R., Silverberg, G., \& Soete, L. (Eds.), Technical Change and Economic Theory (pp. 349-369). London, United Kingdom: Pinter Publishers.

Lundvall, B.-Å. (2007). National Innovation System: analytical focusing device and policy learning tool, Working Paper R2007:004. Östersund, Sweden: ITPS - Swedish Institute for Growth Policy Studies.

Lundvall, B.-Å. (Ed.). (1992). National System of Innovation: Towards a Theory of Innovation and Interactive Learning. London, United Kingdom: Pinter Publishers.

Lüthje, C. (2003). Customers as Co-Inventors: An Empirical Analysis of the Antecedents of Customer-Driven Innovations in the Field of Medical Equipment. Proceedings of the 32th EMAC Conference. Glasgow, Scotland.

Lüthje, C. (2004). Characteristics of Innovating Users in a Consumer Goods Field: An Empirical Study of Sport-related Product Consumers. Technovation, 24(9), 683-695.

Lüthje, C., Herstatt, C., \& von Hippel, E. (2005). User-innovators and "local" information: The case of mountain biking. Research Policy, 34(6), 951965.

Mccormick, S., Brody, J., Brown, P., \& Polk, R. (2004). Public involvement in breast cancer research: An analysis and model for future research. International Journal of Health Services, 34(4), 625-646.

Metcalfe, J.S. (1995). The Economic Foundations of Technology Policy: Equilibrium and Evolutionary Perspective. In Stoneman, P. (Ed.), Handbook of the Economics of Innovation and Technological Change (pp. 409-512). London, United Kingdom: Blackwell.

Metcalfe, J.S. (2003). Equilibrium and Evolutionary Foundations of Competition and Technology Policy: New perspectives on the Division of Labour and the Innovation Process. Revista Brasileira de Inovação, 2(1),111-146.

Minogue V., Boness J., Brown A., \& Girdlestone J. (2005). The impact of service user involvement in research. International Journal of Health Care Quality Assurance, 18(2), 103-112.

Mittra, J. (2016). The New Health Bioeconomy: R\&D Policy and Innovation for the Twenty-first Century. Basingstoke, United Kingdom: Palgrave Macmillan.

Munos, B. (2009). Lessons from 60 years of pharmaceutical innovation. Nature Reviews Drug Discovery, 8, 959-968. 
National Institute for Health Research (2009). Involving patients and the public in medical research: A guide for staff. Retrieved from http://www. involvinglondon.co.uk/RDSPPI/media/PPI-PDFs/brc_userinvolvement_ staffguide.pdf

National Institute for Health Research (2010). Involving Users in the research process: A how to guide for researchers. Retrieved from http://www.rdslondon.nihr.ac.uk/RDSLondon/media/RDSContent/files/PDFs/InvolvingUsers-in-the-Research-Process.pdf

Nelson, R. R. (Ed.). (1993). National innovation systems: a comparative analysis. New York, NY: Oxford University Press.

Oliveira, P., \& von Hippel, E. (2011). Users as Service Innovators: The Case of Banking Services. Research Policy, 40(6), 806-818.

Oliveira, P., Zejnilovic, L., Canhão, H., \& von Hippel, E. (2015). Innovation by patients with rare diseases and chronic needs. Orphanet Journal of Rare Diseases, 10(41). doi: 10.1186/s13023-015-0257-2

Oliver, A. L. (2001). Strategic Alliances and the Learning Life-cycle of Biotechnology Firms. Organization Studies, 22(3), 467-487.

Orsenigo, L., Pammolli, F., \& Riccaboni, M. (2001). Technological change and network dynamics: Lessons from the pharmaceutical industry. Research Policy, 30(3), 485-508.

Pammolli, F., Magazzini, L., \& Riccaboni, M. (2011). The productivity crisis in pharmaceutical R\&D. Nature Reviews Drug Discovery, 10, 428-438.

Polanyi, M. (1967). The tacit dimension. London, United Kingdom: Routledge \& Kegan Paul.

Powell, W.W. (1990). Neither market nor hierarchy: network forms of organization. Research in Organizational Behavior, 12, 295-336.

Powell, W.W., \& Grodal, S. (2005). Networks of innovators. In: Fagerberg, J., Mowery, D.C., Nelson, R.R. (Eds.), The Oxford Handbook of Innovation (pp. 56-85). Oxford, United Kingdom: Oxford University Press.

Powell, W.W., Koput, K., \& Smith-Doerr, L. (1996). Interorganizational collaboration and the locus of innovation: networks of learning in Biotechnology. Administrative Science Quarterly, 41(1), 116-145.

Powell, W.W., White, D.R., Koput, K.W., \& Owen-Smith, J. (2005). Network dynamics and field evolution: the growth of inter-organizational collaboration in the life sciences. American Journal of Sociology, 110(4), 1132-1205.

Prahalad, C.K., \& Hamel, G. (1990). The Core Competence of the Corporation. Harvard Business Review, 68(3), 79-91.

Quéré, M. (2004). The post-genome era: rupture in the organization of the life science industry?. In McKelvey, M., Rickne A. \& J. Laage-Hellman (Eds.), The economic dynamics of modern biotechnology (pp.76-98). Cheltenham, United Kingdom: Edward Elgar.

Rabeharisoa, V. (2003). The struggle against neuromuscular diseases in France and the emergence of the "partnership model" of patient organization. Social Science \& Medicine, 57(11), 2127-2136. 
Rai, Arti K. (2005). Open and Collaborative Research: A New Model for Biomedicine. Intellectual Property Rights in Frontier Industries, 131-158, Duke University School of Law. Retrieved from http://scholarship.law. duke.edu/faculty_scholarship/882

Ramlogan, R., Mina, A., Tampubolon, G., \& Metcalfe, J.S. (2007). Networks of Knowledge: the distributed nature of Medical Innovation. Scientometrics 70(2), 459-489.

Reed, P., Conrad, D.A., Hernandez, S.E., Watts. C., \& Marcus-Smith, M. (2012). Innovation in patient-centered care: lessons from a qualitative study of innovative health care organizations in Washington State. BMC Family Practice, 13:120. doi: 10.1186/1471-2296-13-120

Roijakkers, N., \& Hagedoorn, J. (2006). Inter-firm R\&D partnering in pharmaceutical biotechnology since 1975: Trends, patterns, and networks. Research Policy, 35(3), 431-446.

Rose, D. (2003). Collaborative research between users and professionals: Peaks and pitfalls. Psychiatric Bulletin, 27(11), 404-406.

Rothwell, R. (1992). Successful Industrial Innovation: Critical Factors for the 1990s. R\&D Management, 22(3), 221-239.

Rothwell, R. (1994). Towards the fifth-generation innovation process. International Marketing Review, 11(1), 7-31.

Røtnes, R., \& Staalesen, P.D. (2009). New methods for user driven innovation in the health care sector. Nordic Innovation Centre. Oslo, Norway: Econ Pöyry AS. Retrieved from http://nordicinnovation.org

Sahlsten, M.J., Larsson, I.E., Sjostrom, B., \& Plos, K.A. (2008). An analysis of the concept of patient participation. Nursing Forum, 43(1), 2-11. doi: 10.1111/j.1744-6198.2008.00090.x.

Shaw, B. (1998). Innovation and new product development in the UK medical equipment industry. International Journal of Technology Management, 15(3-5), 433-445.

Smits, R., \& Boon, W. (2008). The role of users in innovation in the pharmaceutical industry. Drug Discovery Today, 13(7-8), 353-359.

Spekowius, G., \& Wendler, T. (2006). Advances in Healthcare Technology: Shaping the Future of Medical Care. Philips Research Book Series. Dordrecht, Netherlands: Springer.

Stockstrom, C., Lüthje, C., \& Antorini, Y.M. (2010). User-generated techniques: The case of the Adult Fans of LEGO, Workshop on The role of users in the intertwined changes of technology and practice. Helsinki Collegium for Advanced Studies, University of Helsinki, Finland.

Swan, J., Bresnen, M., Mendes, M., Newell, S., Perkmann, M., \& Robertson, M. (2005). Exploring interactivity in biomedical innovation: a framework and case study analysis. Conference proceeding of 6th European Conference on Organisational Knowledge, Learning and Capabilities. Boston, MA, USA. 
Trivedi, P., \& Wykes, T. (2002). From passive subjects to equal partners Qualitative review of user involvement in research. British Journal of Psychiatry, 181(6) 468-472. doi: 10.1192/bjp.181.6.468

Urban, G. I., \& von Hippel, E. (1988). Lead User Analyses for the Development of New Industrial Products. Management Science, 34(5), 569-582.

Vega-jurado, J., Gutiérrez-Gracia, A., \& Fernández-de-Lucio, I. (2009). Does external knowledge sourcing matter for innovation? Evidence from the Spanish manufacturing industry. Industrial and Corporate Change, 18(4), 637-670.

Vence, X., Sánchez, M.C., Rodil, O. (2013). Targeting biomed cluster from a mature pharma industry: the Medicon Valley experience. Technology Analysis and Strategic Management, 25(7), 871-889.

von Hippel, E. (1978a). A customer-active paradigm for industrial product idea generation. Research Policy, 7(3), 240-266.

von Hippel, E. (1978b). Successful industrial products from customer ideas: presentation of a new customer-active paradigm with evidence and implications. Journal of Marketing, 42(1), 39-49.

von Hippel, E. (1986). Lead users: source of novel product concepts. Management Science, 32(7), 791-805.

von Hippel, E. (1988). The Sources of innovation. New York; Oxford: Oxford University Press.

von Hippel, E. (2005). Democratizing Innovation, Cambridge, MA: MIT-Press. von Hippel, E., \& de Jong, J.P.J. (2010). Open, distributed and user-centered: Towards a paradigm shift in innovation policy. Scales Research Reports, Number H201009. Zoetermeer: The Netherlands, EIM Business and Policy Research. Retrieved from http://www.entrepreneurship-sme.eu/ pdf-ez/H201009.pdf

von Hippel, E., \& R. Katz (2002). Shifting Innovation to Users Via Toolkits. Management Science, 48(7), 821-833.

Weigel, S. (2008). The role and importance of a university hospital for the innovation activity in the regional medical device industry: a case study from Switzerland. DRUID-DIME Academy Winter 2008 PhD Conference. Rebild, Denmark.

Wootton I.M., Wood V., \& Cook F. (2008). Who wants expert patient programmes for chronic mechanical spinal pain? an investigation into the value of, and recruitment to, an expert patient programme as part of the physiotherapy management of chronic spinal pain. Physiotherapy, 94(1), 78-84.

World Health Organization (2007). People Centred Health Care: A Policy Framework. World Health Organization Western Pacific Region. Geneva, Switzerland: WHO Press.

World Health Organization (2013). Towards People-Centred Health Systems: An Innovative Approach for Better Health Outcomes. World Health Organization Regional Office for Europe, Division of Health Systems and Public Health. Geneva: Switzerland: WHO Press. 
Yadav, P. (2010). Differential pricing for pharmaceuticals: Review of current knowledge, new findings and ideas for action. A Study conducted for the UK Department for International Development. London, United Kingdom: UK DFID. Retrieved from http://apps.who.int/medicinedocs/ documents/s18390en/s18390en.pdf

Zarghom S., Di Fonzo D., \& Leung F.H. (2013). Does Socioeconomic Status Affect Patients' Ease of Use of a Touch-Screen (iPad) Patient Survey?. Interactive Journal of Medical Research, 2(1), e1.

\begin{abstract}
Polish)
Artykuł zawiera obszerny przegląd literatury na temat zmieniajqcej się roli użytkowników w zakresie innowacji, ze szczególnym naciskiem na sektor opieki zdrowotnej. Użytkownicy zostali szczegółowo przeanalizowani przez wielu badaczy na całym świecie ze względu na ich istotnq rolę jako źródła innowacji, wykraczajqca poza tradycyjne założenie, które postrzega klientów jako zwykłych i pasywnych użytkowników produktów i usług. Zwiększajqca się liczba, ale wciq̨ż niewystarczajq̨ca, wielu badań na ten temat, wykazała korzyści z zaangażowania pacjenta oraz jak bliski i stały zwiqzek między pacjentami a lekarzami może prowadzić do trwałych cykli ulepszeń i innowacji w zakresie skutków zdrowotnych. Oprócz podejścia zorientowanego na użytkownika, innowacyjni pacjenci aktywnie rozwijajq nowe rozwiqzania dla ich własnego leczenia, podobnie jak w przypadku innych pacjentów z podobnymi chorobami.
\end{abstract}

Słowa kluczowe: zaangażowania pacjentów, innowacyjność użytkownika, innowacja zorientowana na użytkownika, interaktywne innowacje, innowacje zdrowotne.

\title{
Biographical note
}

Alexandre Trigo, Ph.D. is a professional in the field of customer experience management and an external researcher at the University of Santiago de Compostela, Spain. He graduated in Business Management, holds an advanced degree in Economics and earned a Ph.D. in Applied Economics. He has extensive experience as an innovation expert in international projects with a number of research papers and reports published on services innovation, collaborative innovation, learning mechanisms in enterprises and innovation policy instruments. 
